\title{
Heritability of colour patterns in a closed population of honeybees
}

\author{
TI Szabo 1*, PL Lefkovitch 2 \\ 1 Agriculture of Canada Research Station, Box 29, Beaverlodge, Alberta, TOH OCO; \\ ${ }_{2}^{2}$ Agriculture Canada Research Program Service, Central Experimental Farm, \\ Ottawa, Ontario, Canada K1A OC6
}

(Received 11 March 1991; accepted 27 January 1992)

\begin{abstract}
Summary - The heritability of colour patterns of honeybee (Apis mellifera) queens, workers and drones, the offspring of the 10th generation of 20 queen families were studied. The queen offspring of the 11 th generation of 10 families were also examined. Colour classifications were made for queens, workers and drones. The heritability of the colour of queens was 0.21 to 0.23 ; of workers 0.32 , and drones 0.39 , all significantly different from zero. It may be possible to breed honeybee families for distinctive colour within closed population breeding with natural mating.
\end{abstract}

heritability / colour / closed population / breeding

\section{INTRODUCTION}

The colour markings of the honeybee are the most frequently used characteristic for identification of a bee race. Despite the importance of this character, very little is known about the inheritance of colour patterns. Roberts and Mackensen (1951) stated that there are at least 7 different loci for genes that affect the colour of the abdomen of honeybees, and concluded that variation in colour was continuous. Woyke (1978) summarised the literature on the heredity of colour patterns. From his experiments, he concluded that the inheritance of colour patterns in the honey bee is governed by 3 major allelic genes having their expression modified by $6-7$ polygenes with alternative alleles for light and dark.

More recent experiments have demonstrated that body colour of Apis cerana workers was influenced by temperature during pupal development (Tsuruta et al, 1989). Similarly, the colour pattern of Apis mellifera queens was influenced by the pupation temperature (Spivak et al, 1990), since at lower temperatures the bees developed more slowly and their colour was darker.

Since the inheritance of colour patterns of queens, workers and drones in a

\footnotetext{
* Present address: Department of Environmental Biology, University of Guelph, Guelph, Ontario, Canada, N1G 2W1.
} 
closed population of honeybees has not been studied the present investigation was conducted.

\section{MATERIALS AND METHODS}

In 1988, the tenth generation of queens from 20 families were reared in a closed population breeding program, and the colour patterns of the queens and those of their queen, worker and drone offspring were evaluated. In addition, the colour patterns of the 11 th generation of queens and their queen offspring was also studied.

The bees came from a closed population breeding program which had commenced in 1979 (Szabo and Lefkovitch, 1987). The honey bee stock had been selected from 10 different apiaries distributed throughout Alberta from stock originally obtained from different queen breeders in California. All colonies had overwintered in Alberta for at least one winter. For the first 4 years (1979-1982), the bees known as "Alberta bees" were selected for honey produc- tion in both northern and southern Alberta with queens mated in geographically isolated locations. Drones were provided from the corresponding breeder colonies of the 2 groups. For the 5 following years (1983-1987) the bees were selected for resistance to chalkbrood disease and in 1988 for hygienic behaviour according to the Newton and Otasiewski (1986) method. Yearly, from 1984-1988, one queen was selected as breeder from each family of 3-6 colonies. Selection was based on the least number of chalkbrood mummies or the highest level of hygienic behaviour. The families selected in northern Alberta will be denoted by $\mathrm{N}$, those from the south by $S$. The original $N$ families were numbered from 1 to 10 and the $S$ families from 11 to 20 . In 1986, and in the following years, the newly reared queens from the 2 groups of families, $\mathrm{N}$ and $\mathrm{S}$, were placed into the same isolated mating yard with drones from all of the 20 families.

In 1989 , for each of the 20 breeder families, one breeder queen and her colony were selected. From each of these breeder queens, 30 queens were reared as described by Szabo and Lefkovitch (1987). From the larvae of each

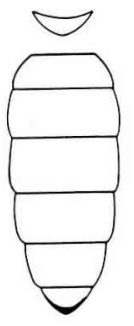

1

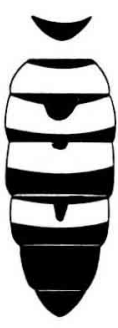

6

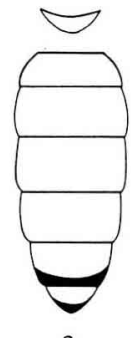

2
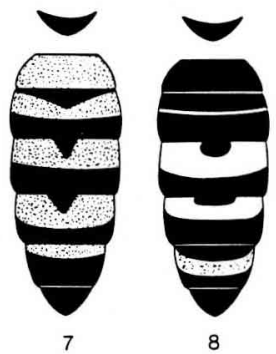

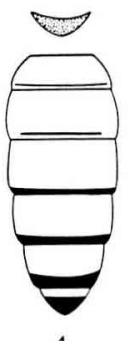

4
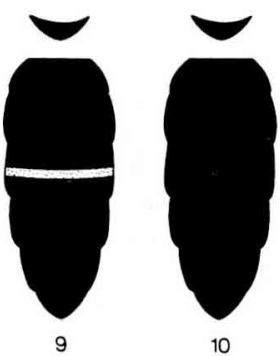

Fig 1. Colour classes of Apis mellifera queens. The white areas represent the different shades of yellow pigmentation. 


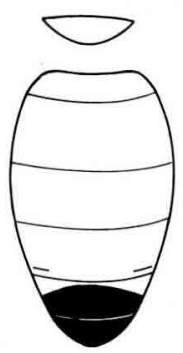

1

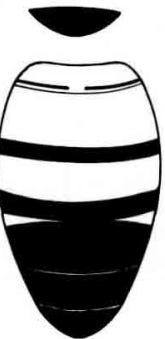

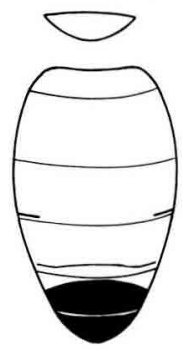

2

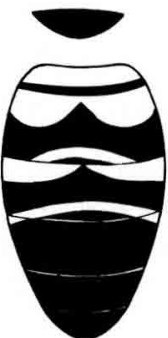

7

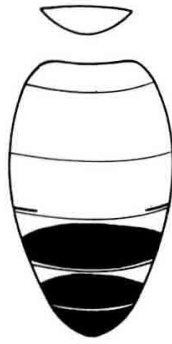

3

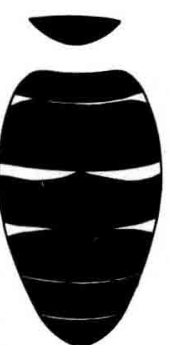

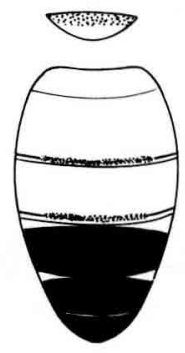

4

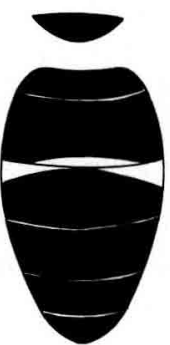

9

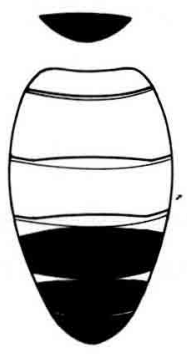

5

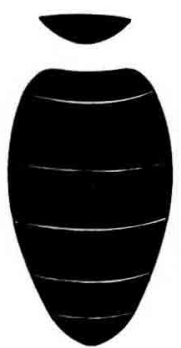

10

Fig 2. Colour classes of honeybee workers. See figure 1 for explanation.

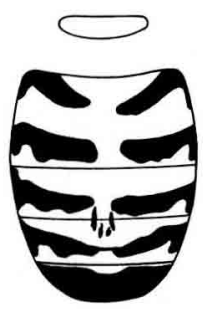

1

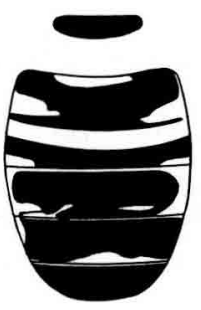

6

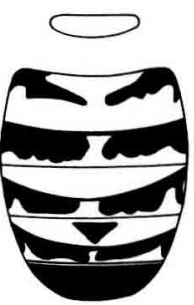

2

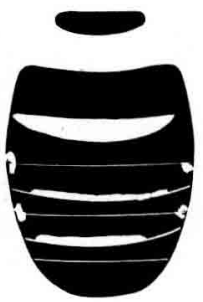

7

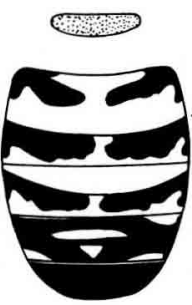

3

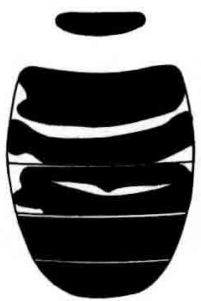

8

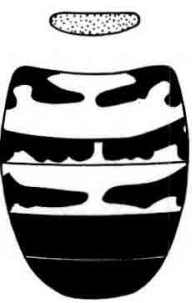

4

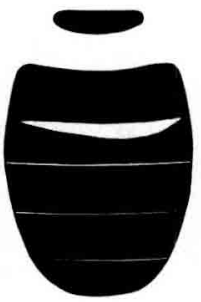

9

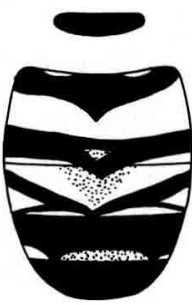

5

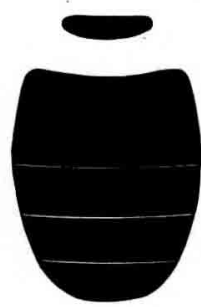

10

Fig 3. Colour classes of honeybee drones. See figure 1 for explanation. 
Table I. Observed data of colour classes of honeybee queens and their offspring as contingency

\begin{tabular}{|c|c|c|c|c|c|c|c|c|c|c|c|}
\hline \multirow{2}{*}{$\begin{array}{c}\text { Family } \\
\text { No }\end{array}$} & \multirow{2}{*}{$\begin{array}{l}\text { Parent } \\
\text { colour } \\
\text { rating }\end{array}$} & \multicolumn{10}{|c|}{ Offspring colour rating } \\
\hline & & 1 & 2 & 3 & 4 & 5 & 6 & 7 & 8 & 9 & 10 \\
\hline
\end{tabular}

a. Dams (1988) and offspring queens (1989)

$\begin{array}{rrrrrrrrrrrr}7 & 1 & 10 & 7 & 2 & 9 & 2 & 0 & 0 & 0 & 0 & 0 \\ 9 & 2 & 1 & 6 & 2 & 12 & 7 & 2 & 0 & 0 & 0 & 0 \\ 11 & 2 & 5 & 8 & 9 & 3 & 2 & 2 & 1 & 0 & 0 & 0 \\ 14 & 2 & 2 & 14 & 4 & 2 & 0 & 0 & 0 & 0 & 0 & 0 \\ 4 & 3 & 0 & 3 & 2 & 7 & 16 & 2 & 0 & 0 & 0 & 0 \\ 6 & 3 & 1 & 8 & 1 & 10 & 8 & 1 & 0 & 1 & 0 & 0 \\ 8 & 3 & 1 & 2 & 9 & 4 & 8 & 1 & 1 & 0 & 1 & 3 \\ 20 & 3 & 4 & 10 & 4 & 10 & 2 & 0 & 0 & 0 & 0 & 0 \\ 1 & 4 & 1 & 3 & 10 & 4 & 6 & 0 & 4 & 1 & 1 & 0 \\ 13 & 4 & 1 & 5 & 3 & 13 & 6 & 1 & 1 & 0 & 0 & 0 \\ 3 & 5 & 2 & 8 & 4 & 4 & 2 & 6 & 1 & 1 & 1 & 1 \\ 12 & 5 & 1 & 2 & 3 & 16 & 3 & 2 & 2 & 1 & 0 & 0 \\ 19 & 5 & 0 & 1 & 1 & 0 & 15 & 9 & 2 & 2 & 0 & 0 \\ 5 & 6 & 0 & 1 & 2 & 8 & 10 & 7 & 1 & 1 & 0 & 0 \\ 17 & 6 & 0 & 1 & 7 & 2 & 3 & 9 & 0 & 3 & 0 & 0 \\ 10 & 7 & 0 & 0 & 2 & 4 & 18 & 3 & 1 & 1 & 1 & 0 \\ 16 & 7 & 0 & 0 & 0 & 1 & 4 & 14 & 4 & 5 & 2 & 0 \\ 2 & 8 & 0 & 1 & 1 & 8 & 9 & 2 & 1 & 3 & 4 & 1 \\ 15 & 9 & 0 & 0 & 4 & 3 & 20 & 3 & 0 & 0 & 0 & 0 \\ 18 & 10 & 0 & 0 & 0 & 2 & 6 & 5 & 1 & 5 & 2 & 9\end{array}$

b. Dams (1988) and offspring workers (1989)

$\begin{array}{rrrrrrrrrrrr}7 & 1 & 11 & 0 & 16 & 3 & 0 & 0 & 0 & 0 & 0 & 0 \\ 9 & 2 & 0 & 3 & 3 & 12 & 1 & 2 & 5 & 2 & 0 & 2 \\ 11 & 2 & 4 & 7 & 8 & 4 & 6 & 0 & 0 & 0 & 1 & 0 \\ 14 & 2 & 0 & 9 & 15 & 6 & 0 & 0 & 0 & 0 & 0 & 0 \\ 4 & 3 & 0 & 0 & 1 & 14 & 15 & 0 & 0 & 0 & 0 & 0 \\ 6 & 3 & 0 & 1 & 6 & 16 & 2 & 5 & 0 & 0 & 0 & 0 \\ 8 & 3 & 1 & 1 & 1 & 1 & 18 & 1 & 0 & 1 & 4 & 2 \\ 20 & 3 & 9 & 5 & 15 & 0 & 0 & 0 & 0 & 1 & 0 & 0 \\ 1 & 4 & 0 & 1 & 3 & 16 & 3 & 0 & 0 & 1 & 0 & 6 \\ 13 & 4 & 2 & 1 & 2 & 6 & 18 & 0 & 0 & 1 & 0 & 0 \\ 3 & 5 & 0 & 0 & 2 & 4 & 8 & 4 & 3 & 6 & 2 & 1 \\ 12 & 5 & 0 & 0 & 2 & 6 & 9 & 6 & 2 & 0 & 0 & 5 \\ 19 & 5 & 0 & 1 & 1 & 1 & 8 & 7 & 1 & 2 & 1 & 8 \\ 5 & 6 & 0 & 0 & 0 & 2 & 4 & 3 & 0 & 1 & 0 & 20 \\ 17 & 6 & 1 & 5 & 6 & 6 & 3 & 1 & 0 & 6 & 0 & 2 \\ 10 & 7 & 0 & 0 & 2 & 2 & 0 & 0 & 0 & 18 & 0 & 8 \\ 16 & 7 & 0 & 0 & 0 & 12 & 5 & 3 & 1 & 2 & 2 & 5 \\ 2 & 8 & 0 & 1 & 0 & 2 & 1 & 11 & 1 & 0 & 0 & 14 \\ 15 & 9 & 0 & 0 & 0 & 6 & 11 & 2 & 2 & 1 & 4 & 4 \\ 18 & 10 & 0 & 0 & 0 & 0 & 6 & 1 & 0 & 1 & 1 & 21\end{array}$


tables.

\begin{tabular}{cccccccccccc}
\hline $\begin{array}{c}\text { Family } \\
\text { No }\end{array}$ & $\begin{array}{c}\text { Parent } \\
\text { colour } \\
\text { rating }\end{array}$ & 1 & 2 & 3 & 4 & 5 & 6 & 7 & 8 & 9 & 10 \\
\cline { 2 - 10 } & & & & & & \multicolumn{1}{c}{ Offspring colour rating } \\
\hline
\end{tabular}

c. Dams (1988) and offspring drones in 1989

$\begin{array}{rrrrrrrrrrrr}9 & 2 & 1 & 4 & 6 & 2 & 2 & 0 & 5 & 1 & 5 & 4 \\ 11 & 2 & 7 & 2 & 2 & 0 & 1 & 1 & 9 & 2 & 4 & 2 \\ 14 & 2 & 0 & 1 & 8 & 6 & 10 & 0 & 3 & 0 & 1 & 1 \\ 4 & 3 & 10 & 9 & 2 & 1 & 2 & 0 & 1 & 0 & 0 & 5 \\ 6 & 3 & 2 & 3 & 6 & 3 & 5 & 2 & 3 & 2 & 2 & 2 \\ 8 & 3 & 2 & 7 & 1 & 0 & 1 & 1 & 12 & 0 & 3 & 3 \\ 20 & 3 & 1 & 3 & 3 & 0 & 3 & 1 & 3 & 7 & 6 & 3 \\ 1 & 4 & 4 & 5 & 2 & 0 & 1 & 0 & 2 & 0 & 4 & 12 \\ 13 & 4 & 1 & 0 & 5 & 2 & 11 & 9 & 0 & 0 & 1 & 1 \\ 3 & 5 & 11 & 5 & 0 & 1 & 0 & 0 & 0 & 0 & 2 & 11 \\ 12 & 5 & 1 & 1 & 1 & 0 & 2 & 7 & 6 & 1 & 3 & 8 \\ 19 & 5 & 2 & 2 & 3 & 0 & 10 & 1 & 3 & 3 & 2 & 4 \\ 5 & 6 & 3 & 4 & 0 & 1 & 0 & 1 & 1 & 1 & 5 & 14 \\ 17 & 6 & 0 & 1 & 1 & 2 & 1 & 1 & 11 & 6 & 3 & 4 \\ 10 & 7 & 1 & 3 & 0 & 0 & 1 & 1 & 6 & 6 & 9 & 3 \\ 16 & 7 & 0 & 0 & 3 & 2 & 2 & 0 & 6 & 2 & 5 & 10 \\ 2 & 8 & 0 & 0 & 1 & 1 & 1 & 0 & 0 & 1 & 8 & 18 \\ 15 & 9 & 0 & 0 & 0 & 0 & 0 & 0 & 1 & 1 & 6 & 14 \\ 18 & 10 & 6 & 3 & 3 & 1 & 2 & 1 & 4 & 1 & 4 & 5\end{array}$

d. Dams (1989) and offspring queens (1990)

\begin{tabular}{rrrrrrrrrrrr}
7 & 1 & 0 & 2 & 3 & 4 & 2 & 3 & 1 & 0 & 1 & 0 \\
11 & 1 & 0 & 1 & 1 & 1 & 0 & 1 & 1 & 0 & 0 & 0 \\
20 & 1 & 0 & 3 & 5 & 1 & 5 & 1 & 0 & 0 & 0 & 0 \\
14 & 3 & 0 & 2 & 4 & 4 & 3 & 1 & 0 & 2 & 0 & 0 \\
4 & 4 & 0 & 0 & 7 & 6 & 3 & 3 & 0 & 0 & 0 & 1 \\
2 & 5 & 0 & 0 & 3 & 0 & 3 & 6 & 0 & 2 & 1 & 0 \\
10 & 8 & 0 & 0 & 0 & 0 & 0 & 3 & 1 & 2 & 0 & 2 \\
17 & 8 & 0 & 0 & 2 & 1 & 0 & 3 & 2 & 2 & 0 & 0 \\
15 & 9 & 0 & 0 & 0 & 1 & 1 & 2 & 0 & 0 & 0 & 1 \\
18 & 10 & 0 & 0 & 0 & 0 & 0 & 0 & 0 & 4 & 16 & 1 \\
\hline
\end{tabular}

Table II. Regression coefficients, heritability and goodness of fit of colour class of dams on their offspring queens, workers and drones. $q=$ queens; $w=$ worker; $d=$ drone.

\begin{tabular}{lllrl}
\hline Predictor & Predicted & Regression (b and se) & $\chi^{2}$ & $h^{2}(\mathrm{se})$ \\
\hline & & & & \\
(a) q 88 & q 89 & $0.4248(0.0335)$ & 160.895 & $0.212(0.017)$ \\
(b) q 88 & w 89 & $0.6194(0.0446)$ & 192.763 & $0.310(0.023)$ \\
(c) q 88 & d 89 & $0.3871(0.0571)$ & 45.932 & $0.387(0.057)$ \\
(d) q 89 & q 90 & $0.4638(0.0593)$ & 61.207 & $0.232(0.030)$ \\
\hline
\end{tabular}


breeder queen, 3 bars of queen cups were grafted and were randomily introduced into 3 different cell builder colonies. The bars were randomly positioned in order to reduce the possible effect of cluster temperature on the colour pattern of the developing queens. After capping, the queen cells were placed in an incubator $\left(34{ }^{\circ} \mathrm{C}\right.$ and $\left.60 \% \mathrm{RH}\right)$. One day prior to emergence, each queen cell was placed in the opening of a small vial provisioned with some queen candy and wood shavings, and then returned to the incubator. Immediately after emergence, the vials with the queens were kept in natural light at room temperature (approximately $22{ }^{\circ} \mathrm{C}$ ) for $24 \mathrm{~h}$, after which the queens were preserved in $70 \%$ ethyl alcohol. In 1990 , this procedure was repeated with the 11 th generation of 10 queen families and their queen offspring.

In June 1989, 30 workers and 30 drones were also collected from the brood combs from each breeder colony. These samples were also preserved in $70 \%$ ethyl alcohol until examination. In contrast with a previous study (Szabo and Lefkovitch, 1988) in which Woyke's (1978) classification for worker colour was used, here drawings of the dorsal part of the abdomen and scutellum of up to 600 individual bees were made from which the 10 colour classes were defined. These ranged from the lightest or most yellow, scored 1, to the darkest or most black, scored 10. All assessments of colour were made by the first author.

The statistical methods used to analyze the data are as follows. Noting that the colour ratings are ordinal (rather than nominal or interval), the number of bees belonging to each colour rating out of 30 adult offspring from queens, workers and drones were assembled into a 2way table in which the classification set for the parental margin was the family and its rating colour, and for the offspring was the colour rating. Thus the separate tables for each parent/ offspring combination are the frequencies of each observed colour combination. Whereas several published procedures for the analysis of ordinal contingency tables exist if just one classification set is ordinal (eg McCullagh, 1980), it appears that satisfactory methods beyong that of Yates (1948; see also McCullagh and Nelder, 1989, exercise 5.7) have yet to be proposed. According to McCullagh (1991), the testing procedure described by Yates is likely to be satisfactory, but that of detailed modelling of the patterns of association in this framework is likely to be less so. Yate's method treats the classification sets symmetrically by assigning the integers, $1,2 \ldots 10$ to the 10 colour categories, and computing the 2 regression coefficients on the assumption that neither margin is logically the predictor of the other. Here, the parental queen colour can be regarded as the predictor of that of the offspring, and so the regression coefficient can be regarded as providing an estimate of heritability, $h^{2}$. According to Collins (1986), for continuous measurements the slope of the regression of offspring on one parent gives a valid measure of $h^{2} / 2$, in contrast with the slope of the regression of offspring on the mid-parental value which measures $h^{2}$ directly. Since drones develop from unfertilized eggs, they have no fathers (but have grandfathers), the queens can be considered as mid-parents of the drones.

Ordinal categorical classifications are often collapsed into smaller tables by fusing subsets of adjacent categories. Since the ordinal nature of the categories is irrelevant for $2 \times 2$ tables, these have been formed to allow some simplification of the conclusions.

\section{RESULTS}

The colour classes of queens, workers and drones are shown in figures 1,2 and 3. Since analyses of these data beyond those reported here are possible, the contingencies are given in full in table la-d. Using Yate's (1948) method, with the colour ratings scored from 1-10, the regression coefficients, their standard errors, and the estimated Pearson chi-squared $\left(\chi^{2}\right)$ were computed (table II). It can be seen that the regression coefficients are approximately 10 times their standard errors, and that the $\chi^{2}$, which have $1 \mathrm{df}$, are significant. Thus the 1988/1989 and 1989/1990 data show a regression relationship which can be interpreted as a 1 generation heritability estimate ranging from about 0.21 to 0.36 , with standard error of about 0.04 (table II). 
Table III. $2 \times 2$ contingency tables of light and dark classes of dams vs light and dark classes of offspring. It = light, colour class 1 to 5 ; $\mathrm{dk}=$ dark, colour class 6 to 10.

\begin{tabular}{|c|c|c|c|c|}
\hline \multirow[t]{2}{*}{ Dams } & \multicolumn{3}{|c|}{ Offspring } & $G^{2}$ \\
\hline & It & $d k$ & total & \\
\hline
\end{tabular}

(a) 1988 Queens, 1989

$\begin{array}{lrrr}\text { It } & 331 & 51 & 382 \\ \text { dk } & 117 & 88 & 205 \\ \text { Total } & 448 & 139 & 587\end{array}$

62.974

(b) 1988 Workers, 1989

$\begin{array}{lrrr}\text { It } & 308 & 82 & 390 \\ \text { dk } & 75 & 135 & 210 \\ \text { Total } & 393 & 217 & 600\end{array}$

110.357

(c) 1988 Drones, 1989

$\begin{array}{lrrr}\text { It } & 186 & 174 & 360 \\ \text { dk } & 43 & 159 & 202 \\ \text { Total } & 229 & 333 & 562\end{array}$

51.909

(d) 1989 Queens, 1990

$\begin{array}{lrrr}\text { It } & 63 & 24 & 87 \\ \text { dk } & 5 & 39 & 44 \\ \text { Total } & 68 & 63 & 131\end{array}$

Table IV. $2 \times 2$ contingency tables for combined data from table III. See explanation in table III.

\begin{tabular}{|c|c|c|c|c|}
\hline \multirow[t]{2}{*}{ Dams } & \multicolumn{3}{|c|}{ Offspring } & \multirow[t]{2}{*}{$G^{2}$} \\
\hline & It & $d k$ & total & \\
\hline
\end{tabular}

\begin{tabular}{lrrrrr} 
(a) 1988 & & \multicolumn{3}{c}{ All combined } \\
It & 825 & 307 & 1132 & \\
dk & 235 & 382 & 617 & 217.586 \\
Total & 1060 & 689 & 1749 &
\end{tabular}

\begin{tabular}{lllrl} 
(b) 1988 & \multicolumn{5}{c}{ Queens and workers, 1989} \\
It & 639 & 133 & 772 & \\
dk & 192 & 223 & 415 & 167.587 \\
Total & 831 & 356 & 1187 & \\
\hline
\end{tabular}

In table IIla-d, the data of table la-d, collapsed into 2 categories for each margin, namely, light (colour categories 1-5), and dark (categories 6-10), are given together with the likelihood ratio chisquared $\left(\mathrm{G}^{2}\right)$ test for marginal independence. In addition, 2 more 2-way tables were formed based only on the queens in 1988 as predictors, namely, for all offspring combined in 1989 (table IVa) and for just the females, excluding the drones (table IVb). For all tables, there is strong evidence against independence.

\section{DISCUSSION}

Roberts and Mackensen (1951) stated that there are at least 7 different loci for genes that affect the colour of the abdomen of the honeybee, and that these pairs of genes can produce 2187 different genotypes. Concerning our entire closed population, the colour pattern appears to be continuous from the lightest (1) to the darkest (10). However, this is not the case in the individual families. In 1979, at the start of the program, there were breeder families with distinctive colour patterns for which a number of families continued to exhibit distinct patterns after 10 years of closed population breeding. We demonstrated that colour pattern appears heritable to a great extent since the estimated heritabilities are from 0.21 to 0.39 (table II). The sex ratio in the ancestral lineage of the honey bee is $61.8 \%$ females and $38.2 \%$ males, and theoretically the major contribution to the gene pool must be assigned to the queens (Adam, 1987).

The factors by which some of the families are able to retain their distinctive colour pattern may be understood in the light of the observations of Koeniger et al 
(1989). In a mixed population of $A$ mellifera ligustica and $A$ mellifera carnica, there was a significant tendency for assortive mating in both groups of queens. One of the mechanisms of mate choice may involve the differences in vertical distribution of the drones.

That different colour patterns are seen in different races of honey bees is of itself strong evidence for the existence of its high heritability; in fact, response to selection for colour is well attested in this species. While the differences we observed among the families may be no more than a reflection of the genetic heterogeneity in the founding stock, we believe that the remarkable differences we found may be important for practical purposes. Our findings may facilitate the breeding of honey bees using visibly recognizable characteristics linked to those of economic and management value, as in other domestic animals and in the breeding of cultivars of agricultural crops.

Résumé - Héritabilité de la coloration dans une population fermée d'abeilles (Apis mellifera L). On a étudié l'héritabilité de la coloration des reines, des ouvrières et des mâles d'abeille dans la descendance de la $10^{\circ}$ génération de 20 familles de reines. Les reines issues de la $11^{\circ}$ génération de 10 familles ont été également examinées. Toutes les abeilles provenaient d'un programme de sélection en population fermée démarré en 1979 (Szabo et Lefkovitch, 1987). Constituée à l'origine par des achats chez divers éleveurs de reines de Californie, cette souche d'abeilles avait été constituée à partir de divers ruchers répartis dans tout l'Alberta. Pendant les 4 premières années du programme (1979-1982), la sélection a porté sur la production de miel dans le Nord et dans le Sud de l'Alberta; les 5 années sui- vantes, sur la résistance au couvain plâtré et en 1988 sur le comportement hygiénique. À partir de 1986, les nouvelles reines élevées dans les 2 groupes de familles (Nord et Sud) ont été placées dans le même rucher de fécondation, géographiquement isolé et alimenté avec des mâles provenant des 20 familles.

Une classification en 10 degrés de la couleur de l'abdomen a été établie séparément pour les reines, les ouvrières et les mâles (figs 1-3). L'héritabilité $\left(h^{2}\right)$ a été calculée à partir de la régression de la coloration de la descendance sur celles des génitrices. La $h^{2}$ de la coloration de la descendance $1988 / 1989$ a été de 0,21 pour les reines, de 0,31 pour les ouvrières et de 0,39 pour les mâles. Elle a été de 0,23 pour la descendance reines 1989-1990. Toutes les estimations étaient significativement différentes de zéro. II semble possible de sélectionner des familles d'abeilles en fonction de la coloration au sein d'une population fermée par accouplement naturel.

héritabilité / coloration / population fermée / sélection

Zusammenfassung - Die Heritabilität
des Färbungsmusters in einer ge-
schlossenen Population von Honigbienen. Es wurde die Heritabilität des Färbungsmusters von Königinnen, Arbeiterinnen und Drohnen der Honigbiene (Apis mellifera) in der Nachkommenschaft der 10e Generation von 20 KöniginnenFamilien bestimmt. Von der 11e Generation wurden außerdem aus 10 Familien Königinnen untersucht. Alle Bienen stammten aus einem Zuchtprogramm mit einer geschlossenen Population, das im Jahre 1979 begonnen worden war (Szabo und Lefkovitch, 1987). Die Bienenstämme kamen von verschiedenen Ständen aus 
ganz Alberta (Kanada), ursprünglich waren sie aber von verschiedenen Königinnenzüchtern in Kalifornien gekauft worden. In den ersten vier Jahren des Programms (1979-1982) wurden die Bienen sowohl in Nord wie in Südalberta auf Honigleistung selektiert, in den folgenden fünf Jahren (1983-1987) auf Kalkbrutresistenz und im Jahre 1988 auf hygienisches Verhalten. Im Jahre 1986 und in den folgenden Jahren wurden die Jungköniginnen aus den beiden Familiengruppen, $\mathrm{N}$ und $\mathrm{S}$, auf derselben isolierten Paarungsstelle zusammen mit Drohnen aus allen 20 Familien aufgestellt.

Getrennt für Königinnen, Arbeiterinnen und Drohnen wurde ein Klassifikationsschema der Färbung des Hinterleibs in 10 Stufen aufgestellt (Abb 1-3). Die Heritabilität wurde aus der Regression des Farbmusters der Nachkommen auf das der mütterlichen Zuchttiere berechnet. Das $h^{2}$ des Farbmusters berechnet aus der Nachkommenschaft des Jahres 1988/1989 betrug für Königinnen 0,21 ; für Arbeiterinnen 0,31 , und für Drohnen 0,39 . Das $h^{2}$ des Farbmusters der 1989/1990 aufgezogenen Königinnen betrug 0,23 . Alle Schätzungen waren signifikant verschieden von Null. Es erscheint möglich, in einer geschlossenen Population Bienenfamilien auf ein bestimmtes Farbmuster auf dem Wege der natürlichen Paarung zu züchten.

\section{Heritabilität / Färbung / geschlossene Population / Zucht}

\section{REFERENCES}

Brother Adams (1987) Breeding the Honeybee. Northern Bee Books, Hebden Bridge, Mytholmroyd
Collins AM (1986) Quantitative genetics. In: Bees Genetics and Breeding (Rinderer TE, ed) Academic Press, Orlando, Florida, 283304

Koeniger G, Koeniger N, Pechhacker H, Ruttner $F$, Berg S (1989) Assortative mating in a mixed population of European honeybees, Apis mellifera ligustica and Apis mellifera carnica. Insectes Soc 36, 129-138

Mc Cullagh P (1980) Regression models for ordinal data (with discussion). J $R$ Stat Soc B42, 109-142

McCullagh P, Nelder JA (1989) Generalized Linear Models. Chapman and Hall, London, 2nd edn

Newton DC, Ostasiewski NJ Jr (1986) A simplified bioassay by behavioral resistance to American foulbrood in honey bees (Apis mellifera L). Am Bee J 126, 278-281

Roberts WC, Mackensen O (1951) Breeding improved honey bees. II. Heridity and variation. Am Bee J 91, 328-330

Spivak M, Zeltzer A, DeGrandi-Hoffman G, Martin JH (1990) The influence of pupation temperature on the colour patterns and development time of queen honey bees. Am Bee $J$ 130,814

Szabo TI, Lefkovitch LP (1987) Fourth generation of closed population honeybee breeding. 1. Comparison of selected and control strains. J Apic Res 26, 170-180

Szabo TI, Lefkovitch LP (1988) Fourth generation of closed population honeybee breeding. 2. Relationship between morphological and colony traits. Apidologie 19, 259-274

Tsurula T, Matsuka M, Sasaki M (1989) Temperature as a causative factor in the seasonal colour dimorphism of Apis cerana japonica workers. Apidologie 20, 149-155

Woyke J (1978) Biology of reproduction and genetics of the honeybee. Final Technical Report, Warsaw, Agric Univ

Yates $F$ (1948) The analysis of contingency tables with groupings based on quantitative characters. Biometrika 35, 176-181 